\title{
关于基层党校党性教育教学设计的思考
}

周俣含

重庆市大渡口区委党校

DOI:10.32629/er.v2i7.1912

[摘 要] 党性教育要贯穿党校培训全过程, 是党校培训工作的重点。党性教育的教学设计是党性教育的关键环节。只有科学 把握党性教育的教学设计,充分考虑到目标、内容、方式方法等环节,才能使党性教育入脑入心。

[关键词] 党性教育; 教学设计; 思考

党性教育的教学设计与党性教育效果密切相关。加强党 性教育教学设计研究, 突出问题导向, 科学把握教学设计的 基本流程, 引领和帮助党员干部保持政治上的清醒和坚定。 主要抓好以下四个方面:

\section{1 党性教育的重要性}

党性教育是党校教育内容的核心, 党校应当重视党性教 育并将其渗透到党校能力教育、理论教育的全过程, 才能更 好地把握党校工作的方向。近年来, 党校内的学员们逐渐年 轻化, 有着充沛的精力, 自身文化程度较高, 有强烈的求知欲, 对新鲜事物的接受能力较强, 这是他们在党校学习的优势, 但是这些人参加工作的时间较短, 入党时间不长, 对于马列 主义、中国特色社会主义理论体系还不够了解, 在改革开放 的环境中, 容易受到外来思想的冲击与影响。因此, 必须重视 党校中的党性教育, 才能完成党校培养我党干部队伍的目标 需求。

\section{2 明确党性教育的主要目标}

党性教育的主要目标应体现在以下几个方面:

2.1 明确政治方向。让各级干部明确政治方向, 站稳政治 立场, 遵守政治纪律, 提高政治鉴别力, 增强政治敏锐性, 牢 固树立正确的世界观、人生观、价值观, 永葆共产党人的先 进性和纯洁性。

2.2坚定理想信念。使各级干部筑牢理想信念的理论支 撑, 坚持用马克思主义的立场、观点、方法来认识世界, 认识 人类社会发展的客观规律, 自觉运用辩证唯物主义和历史唯 物主义的强大思想武器, 把理想信念建立在科学分析和理性 基础上。

2.3增强宗旨意识。让各级干部树立正确的权力观、政 绩观、群众观，坚决反对 “四风”, 始终保持党同人民群众 的血肉联系。

2.4坚持组织原则。增强党员干部民主集中制观念, 促使 各级干部坚持民主集中制的根本组织制度, 充分发扬民主, 自觉维护中央权威, 服从组织决定, 维护党的团结和统一。

2.5树立优良作风。促使各级干部树立好的思想作风、 工作作风、生活作风, 明白做人做官的道理, 清楚自己的底线 在哪里, 正确辨别是与非、对与错, 永远怀着一颗为民之心。

\section{3 确定党性教育的内容}

根据《2018-2022年全国干部教育培训规划》《中共中 央关于加强和改进新形势下党校工作的意见》《中共重庆市 委关于加强和改进新形势下党校工作的实施意见》, 重点设 计包括党性理论教育、理想信念教育、宗旨意识教育、党史 国史教育、革命传统教育、道德品行教育、法治思维教育、 反腐倡廉教育为主要内容的系统化党性教育, 着重开展 “不 忘初心、牢记使命” 主题教育, 推进 “两学一做” 学习教育 常态化制度化。大力开展 “以案说纪、以案说法、以案说德、 以案说责” 警示教育, 努力增强学员的纪律、法治、政德及 责任意识。

\section{4 丰富党性教育的方式方法}

积极探索和完善研讨式教学、案例式教学、演讲辩论教 学、体验式教学、情景模拟式教学, 适当增加现场教学、“现 身说法” 教学的权重, 努力把经济社会发展的现场、革命旧 居旧址和警示教育基地转化为 “课堂”, 把基层和群众的生 动实践以及在实践基础上总结出来的鲜活经验转化为 “教 材”, 把各条战线上的先模人物转化为 “教师”, 用身边人、 身边事, 教育、说服身边人, 用看得见、摸得着的实践成果, 增强理论教育和党性教育的惨透力、穿透力和震撼力。

\section{5 抓好教学活动的关键节点}

5.1 抓好需求调研, 加强培训针对性时效性和吸引力。要 在深入研究党校教育规律和干部成长规律的基础上, 探索党 性教育的特点和规律。认真研究党性教育对象的特点, 坚持 分层次、分类别, 切实增强党性教育的针对性实效性和吸引 力感染力。

5. 2 抓好培训起步, 做实入学教育。在入学前专门集中时 间进行入学教育, 强调党性教育的重要意义, 明确党性教育 目标与任务, 增强主业主课意识, 快速进入学习状态, 实现 “三个转变”。建立参训学员党性自查分析表, 掌握学员思想 动态, 为因材施教提供依据。

5. 3抓好学风建设, 坚持从严管理。从考勤纪律、课堂纪 律、学习考核、就餐管理等方面对区委党校学员提出严格、 细化要求, 进一步强化学员的纪律意识、规矩意识, 党校各级 各类管理人员要高质量地做好各项管理服务工作, 以实际行 动体现党性原则, 营造党性教育的良好氛围。

5.4 抓好中程重点, 做实党性锻炼。规范完善党性分析流 
程及要求, 撰写高质量的党性分析报告。组织好学员支部定 期开展 “主题党日活动”, 增强党性锻炼的严肃性、针对性。

5.5 抓好实岗锻炼, 提升服务能力。紧密围绕密切联系群 众这一主题, 策划、组织、实施系列活动内容; 明确载体, 主要有 “三个一”, 即上好一次理论专题课、开展一次角色 体验、组织一次专题调研。

5. 6抓好结尾升华, 严肃组织生活。在结业前召开一次严 肃、认真、高质量的组织生活会, 作为党性教育 “最后一公 里” 来抓, 促进学员思想上、精神上的内在反思和自省。

5.7抓好监督评估, 建立长效机制。要探索健全 “述、评、 考” 以及和学风建设档案等制度, 探索党性教育考评考核的 细化量化办法, 把学风是否端正、党性锻炼是否扎实, 是否系 统掌握理论并运用理论指导实践作为重要内容, 形成长效机 制。通过训用紧密结合进一步形成正确的导向, 从根本上解 决少数学员认为在党校 “学与不学、学多与学少、学得好与 学得不好一个样” 的思想。

\section{6 提高党校教育有效性的途径研究}

6. 1在教学内容上, 突破理论专题界限, 适当增加环节理 论为实践提供指导, 是实践活动的基础, 因此理论教学环节 仍是党校育人环节的重中之重。

在教学内容上, 应克服现有的不足, 除开设党的理论知 识专题外, 增加其他系列专题讲座。其一, 社会热点专题。“90 后” 的大学生梦想成功, 他们关心国家时事政治、关注社会 焦点话题, 因此在党校理论教育部分可适当增加此环节, 党 校教师以自身独到的见解为学员答疑解惑, 体现党校教育的 时代性, 增强党校的吸引力。其二, 先锋教育专题。先锋教育 培养先锋人才, 通过此环节进一步树立党校学员的先进意识, 提高对自身的要求。其三, 开展仪式教育。从思想政治教育 的角度来看, 仪式是一种以文化为载体, 并由文化传统所规 定的特有的情境教育与学习方式, 它能呈现思想政治教育的 内容, 丰富思想政治教育载体, 并以其特有的形式创设出相 应的环境, 以情境教化、凝聚、升华和固化对象的相关情感, 通过现场营造的气氛来唤起参与者相似的内部情感而实现 教育目的。

6.2 在师资队伍上, 跨越学校、年龄界限, 充实人才库。 鉴于目前党校师资来源单一的现状, 可适当扩大党校教师后 备人才库, 进一步提升现有的党校教师人才库的质量。其一, 聘请立场坚定、党性修养高、有丰富党务工作经验的退休老
党员或优秀企业家代表担任教师。其二, 高校党校可考虑与 地方党校建立联合共建机制, 实现资源上的共享, 信息上的 互通。其三, 在党校教育环节中增加朋辈教育, 安排高年级同 学给低年级同学上党课, 如科研团队、爱心团队、文艺团队 的宣讲等, 通过党校的平台, 鼓励大学生百花齐放、百家争 鸣。同时, 为保证党校教师的教学质量, 增强教师投身党校教 学的积极性, 学校应建立相应的激励制度, 将党课纳入教学 评估, 作为教师一年的教学工作量进行考核。

6. 3在教学形式上, 集课堂教学、实践教学、网络教学为 一体。实践教学设置的目的是为了让党校学员将平时所学应 用到实践中, 进一步巩固理论, 升华思想, 体现理论与实践的 相结合, 在实践中寻找赠人玫瑰的快乐, 发扬先锋模范作用。 针对现有实践活动形式单一、号召力不强的不足, 可从以下 两方面实现突破: 首先, 深化实践服务内涵。为增强实践活 动的吸引性, 动员更多的学员广泛参与, 由学校或学院牵头, 与地方政府或相关的企事业单位合作，建立校外党校教育实 践基地, 克服服务内容低端的不足, 进一步挖掘服务内涵, 让 学员结合所学的专业知识去服务地方经济, 更能激发他们的 兴趣。其次, 拓宽实践活动形式。在实践活动形式上我们不 应仅限于日常活动, 也可适当拓宽。如对某一个嘉兴现象展 开问卷调查, 分析其存在的原因, 为嘉兴市政府建言献策, 真 正体现当代大学生的价值或者通过出海报等形式引发广大 市民文明出行, 帮助市政府打造文明城市的重大工程, 创造 形成 “物质丰富、精神富有” 这一两富社会目标宣传工作的 氛围。

抓好教学设计这个 “牛鼻子”, 增强党性教育的惨透力、 穿透力和震撼力, 使学员通过党校培训, 真正在理论上得到 提高、精神上得到塑造、思想上得到升华。

[参考文献]

[1]张富玉,赵学信.浅议党校教师形象的培养[J]. 学习论 坛,1999(01):38.

[2]锁兴义.建设高素质千部队伍关键要提高党校教师素 质[J]. 创造,2001(08):49-50.

[3]黄显霞,孙淑军.跨世纪党校教师应具备的素质[J].兵 团党校论坛, 1998(02):40-41.

\section{作者简介:}

周俣含(1982--), 重庆人, 汉族, 硕士研究生, 重庆市大渡 口区委党校教务科科长, 讲师, 研究方向: 思想政治教育。 